\title{
Endoscopic resection and the T category: Baby steps toward risk stratification
}

\author{
Virginia R. Litle, MD
}

\footnotetext{
From the Division of Thoracic Surgery, Department of Surgery, Boston University School of Medicine, Boston, Mass.

Disclosures: Author has nothing to disclose with regard to commercial support.

Received for publication Aug 17, 2017; accepted for publication Aug 18, 2017; available ahead of print Sept 12 2017.

Address for reprints: Virginia R. Litle, MD, Division of Thoracic Surgery Department of Surgery, Boston University, 88 E Newton St, Collamore 7380, Boston, MA 02118 (E-mail: Virginia.litle@bmc.org).

J Thorac Cardiovasc Surg 2017;154:1785-6

$0022-5223 / \$ 36.00$

Copyright (c) 2017 by The American Association for Thoracic Surgery

http://dx.doi.org/10.1016/j.jtcvs.2017.08.029
}

In the 1991 movie What About Bob?, the psychiatrist character played by Richard Dreyfus is ironically driven catatonic by to an "inherited" patient played by Bill Murray. By being crazy and fun, the Murray character was able to take control away from the pathologic narcissist played by Dreyfus. To advance the management of esophageal cancer, you have to be crazy (think minimally invasive esophagectomy, endoscopic mucosal resection and robotically assisted minimally invasive esophagectomy) but also have fun (collaborate) to gain control of this pathology. Patients with early-stage esophageal adenocarcinoma (EAC) provide a particular clinical challenge. We perform an esophagectomy and accept a high perioperative morbidity and mortality risk. We perform an endoscopic mucosal resection and worry that we are undertreating. Are we between a rock and a hard place? No; clinical management is slowly evolving, but molecular translational efforts need to contribute to progress.

In this issue of the Journal, Weksler and colleagues ${ }^{1}$ take baby steps toward a better understanding of how best to proceed with management of superficial EAC. Risk stratification models have been proposed earlier, ${ }^{2}$ but Weksler and colleagues ${ }^{1}$ developed an algorithm based on a retrospective review from the National Cancer Database. Advantages of their study: a large database. Limitations? Missing data, an inability to review the pathology slides, lack of esophagectomy data, and nodal understaging. This is still, however, a step forward. EAC is an uncommon cancer and thus a challenge to study. Validation of a prognostic risk stratification system may be impossible. But as the alternative is worse-patients die-we need to keep taking small steps forward.

What limits progress? We still have a major knowledge gap: a robust molecular profile for nodal involvement. From a small, albeit multi-institutional, series of T1 tumors, we know lymphovascular involvement, differentiation and tumor size can be used to provide a scoring system to predict nodal involvement. ${ }^{2}$ Identification of positive nodes

\section{References}

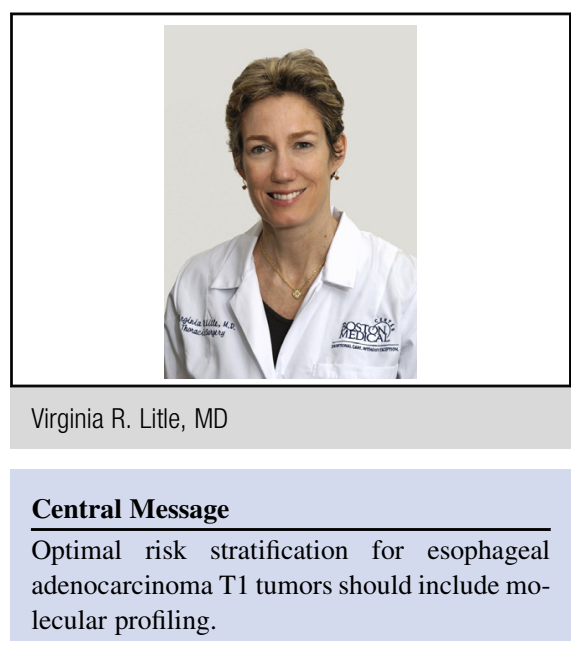

See Article page 1787.

with molecular techniques has been applied to more common thoracic malignancies, such as non-small cell lung cancer, ${ }^{3}$ and microRNA arrays have been used to identify 3 microRNAs associated with EAC nodal positivity. ${ }^{4}$ Additional applications of gene profiling from large series can sort out the miscreant early cancers, ${ }^{5-7}$ whereas some investigators report a single molecular marker to distinguish a bad phenotype. ${ }^{8}$ Of course, these are likely not disparate features; rather, they all need to be wrapped into the negative performance profile (risk of nodal involvement, risk of recurrence), and certainly some variables may be surrogates for others. It is complicated, because not all tumor gene expression at the RNA level translates into actionable items to address.

How do baby steps add up to a giant step forward when studying an uncommon cancer? Bioinformatics, publicly available data, and old-fashioned pathology are the requisite tools. Collaboration with respect to resources and cases will allow testing of cases and validation of proposed risk stratification systems. Focus on the profile and collaborate as teams. Baby steps are small but forward steps for advancement.

1. Weksler B, Kennedy KF, Sullivan JL. Using the National Cancer Database to create a scoring system that identifies patients with early-stage esophageal cancer at risk for nodal metastases. J Thorac Cardiovasc Surg. 2017;154:1787-93.

2. Lee L, Ronellenfitsch U, Hofstetter WL, Darling G, Gaiser T, Lippert C, et al. Predicting lymph node metastases in early esophageal adenocarcinoma using a simple scoring system. J Am Coll Surg. 2013;217:191-9. 
3. Xi L, Coello MC, Litle VR, Raja S, Gooding WE, Yousem SA, et al. A combination of molecular markers accurately detects lymph node metastasis in non-small cell lung cancer patients. Clin Cancer Res. 2006;12:2484-91.

4. Feber A, Xi L, Pennathur A, Gooding WE, Bandla S, Wu M, et al MicroRNA prognostic signature for nodal metastases and survival in esophageal adenocarcinoma. Ann Thorac Surg. 2011:91:1523-30.

5. Ismail A, Bandla S, Reveiller M, Toia L, Zhou Z, Gooding WE, et al. Early $\mathrm{G}_{1}$ cyclin-dependent kinases as prognostic markers and potential therapeutic targets in esophageal adenocarcinoma. Clin Cancer Res. 2011;17:4513-22.
6. Pennathur A, Xi L, Litle VR, Gooding WE, Krasinskas A, Landreneau RJ, et al. Gene expression profiles in esophageal adenocarcinoma predict survival after resection. J Thorac Cardiovasc Surg. 2013;145:505-12; discussion 512-3.

7. Ong CA, Shapiro J, Nason KS, Davison JM, Liu X, Ross-Innes C, et al. Three-gene immunohistochemical panel adds to clinical staging algorithms to predict prognosis for patients with esophageal adenocarcinoma. J Clin Oncol. 2013;31:1576-82.

8. Li Z, Zou X, Xie L, Chen H, Chen Y, Yeung SC, et al. Personalizing risk stratification by addition of PAK1 expression to TNM staging: improving the accuracy of clinical decision for gastroesophageal junction adenocarcinoma. Int J Cancer. 2015;136:1636-45. 